\title{
Acute $\beta$-blockade prevents myocardial $\beta$-adrenergic receptor desensitization and preserves early ventricular function after brain death
}

\author{
Prakash K. Pandalai, MD, ${ }^{a}$ Kelly M. McLean, MD, ${ }^{a, b}$ Christian F. Bulcao, MD, MBA, ${ }^{a}$ Jodie Y. Duffy, PhD, a,b \\ Karen M. D'Souza, PhD, ${ }^{a}$ Walter H. Merrill, MD, ${ }^{a}$ Jeffrey M. Pearl, MD, ${ }^{b}$ and Shahab A. Akhter, MD ${ }^{a}$
}

Objective: $\beta$-Adrenergic receptor desensitization through activation of the $\mathrm{G}$ proteincoupled receptor kinase 2 is an important mechanism of early cardiac dysfunction after brain death. We hypothesized that acute $\beta$-blockade can prevent myocardial $\beta$-adrenergic receptor desensitization after brain death through attenuation of $\mathrm{G}$ protein-coupled receptor kinase 2 activity, resulting in improved cardiac function.

From the Department of Surgery, Section of Cardiothoracic Surgery, University of Cincinnati College of Medicine, ${ }^{\mathrm{a}}$ and Pediatric Cardiothoracic Surgery, Cincinnati Children's Hospital Medical Center, ${ }^{\mathrm{b}}$ Cincinnati, Ohio.

Supported by the National Institutes of Health (HL081472 to SAA, T32 HL007382-29 to PKP, and P021-040-N366 to KMM) and a research award from the American Surgical Association Foundation (to SAA).

Received for publication May 31, 2007; accepted for publication Sept 6, 2007.

Address for reprints: Shahab A. Akhter, Assistant Professor of Surgery, Section of Cardiac \& Thoracic Surgery, The University of Chicago, $5841 \mathrm{~S}$. Maryland Avenue, MC 5040, Chicago, IL 60637 (E-mail: sakhter@ surgery.bsd.uchicago.edu)

J Thorac Cardiovasc Surg 2008;135:792-8

$0022-5223 / \$ 34.00$

Copyright $\odot 2008$ by The American Association for Thoracic Surgery

doi:10.1016/j.jtcvs.2007.09.038

Methods: Adult pigs underwent either sham operation, induction of brain death, or treatment with esmolol ( $\beta$-blockade) for 30 minutes before and 45 minutes after brain death ( $\mathrm{n}=8$ per group). Cardiac function was assessed at baseline and for 6 hours after the operation. Myocardial $\beta$-adrenergic receptor signaling was assessed 6 hours after operation by measuring sarcolemmal membrane adenylate cyclase activity, $\beta$-adrenergic receptor density, and G protein-coupled receptor kinase 2 expression and activity.

Results: Baseline left ventricular preload recruitable stroke work was similar among sham, brain death, and $\beta$-blockade groups. Preload recruitable stroke work was significantly decreased 6 hours after brain death versus sham, and $\beta$-blockade resulted in maintenance of baseline preload recruitable stroke work relative to brain death and not different from sham. Basal and isoproterenol-stimulated adenylate cyclase activities were preserved in the $\beta$-blockade group relative to the brain death group and were not different from the sham group. Left ventricular $G$ protein-coupled receptor kinase 2 expression and activity in the $\beta$-blockade group were markedly decreased relative to the brain death group and similar to the sham group. $\beta$-Adrenergic receptor density was not different among groups.

Conclusion: Acute $\beta$-blockade before brain death attenuates $\beta$-adrenergic receptor desensitization mediated by $\mathrm{G}$ protein-coupled receptor kinase 2 and preserves early cardiac function after brain death. These data support the hypothesis that acute $\beta$-adrenergic receptor desensitization is an important mechanism in early ventricular dysfunction after brain death. Future studies with $\beta$-blocker therapy immediately after brain death appear warranted.

$\mathrm{T}$ he incidence of heart failure (HF) continues to increase in the United States and worldwide. Despite advances in medical therapy, the average survival for patients diagnosed with HF is approximately 5 years. ${ }^{1}$ Although the most effective long-term therapy for end-stage HF is cardiac transplantation, this remains an extremely limited option because of the donor organ shortage. Adding to donor limitations, nearly $25 \%$ of potential heart donors are found to have significantly depressed myocardial function without evidence of structural heart disease and therefore are not considered for organ procurement. The etiology of ventricular dysfunction after brain death (BD) is likely multifactorial, and previously reported hypotheses include ischemic injury, ${ }^{2}$ direct catecholamine-induced myocardial injury, ${ }^{3}$ and impaired $\beta$-adrenergic receptor $\left(\beta\right.$-AR) signaling. ${ }^{4}$ 


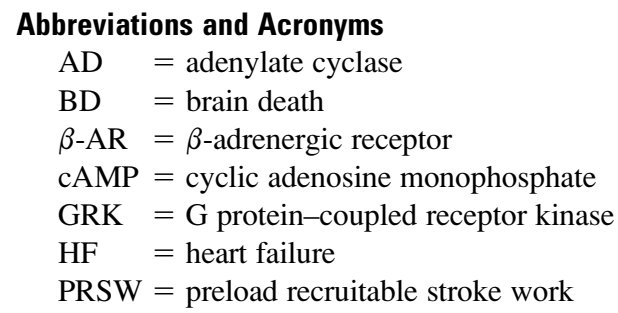

G protein-coupled receptor kinases (GRKs) are serinethreonine kinases that phosphorylate agonist-occupied $\mathrm{G}$ protein-coupled receptors, leading to receptor-effector uncoupling, or desensitization. GRK2, the primary GRK expressed in the heart, plays an important role in regulating $\beta$-AR signaling and cardiac function. ${ }^{5,6}$ We recently demonstrated in a porcine model that impaired $\beta$-AR signaling after $\mathrm{BD}$ is mediated by elevated GRK2 activity and contributes to the cardiac dysfunction seen after BD. ${ }^{7}$ We hypothesized that the catecholamine surge resulting from BD leads to activation of myocardial $\beta$-ARs and subsequent activation of GRK2. This in turn leads to desensitization of myocardial $\beta$-ARs, decreased intracellular cyclic adenosine monophosphate (cAMP) production, and depressed ventricular function. In this study, we hypothesized that this effect of BD on early cardiac function might be prevented by inhibiting activation of GRK2 with intravenous $\beta$-blocker therapy. We used a validated porcine model of BD and ventricular dysfunction to study the effects of esmolol administration on cardiac function and the myocardial $\beta$-AR signaling system.

\section{Materials and Methods}

All animals received humane care and treatment in compliance with the "Principles of Laboratory Animal Care" formulated by the National Society for Medical Research and in accordance with the "Guide for the Care and Use of Laboratory Animals" (www.nap.edu/catalog/5140.html). The animal care and use committee at Children's Hospital Research Foundation also approved the protocol.

\section{Model of Donor Heart Dysfunction}

Crossbred adolescent pigs $(20-35 \mathrm{~kg})$ were anesthetized with ketamine $(20 \mathrm{mg} / \mathrm{kg}$ intramuscularly) and acepromazine $(1.1 \mathrm{mg} /$ $\mathrm{kg}$ intramuscularly), intubated, and ventilated. A 22F Fogarty occlusion catheter (Baxter Healthcare Corporation CardioVascular Group, Irvine, Calif) and an open-lumen pressure catheter (Medtronic, Inc, Minneapolis, Minn) were placed into the subdural space through a frontoparietal burr hole. A LaserFlo laser Doppler blood perfusion monitor (Vasamedics LLC, St Paul, Minn) was inserted directly into the brain. Animals were assigned to one of the following three protocols $(\mathrm{n}=8$ per group): sham operation without $\mathrm{BD}$ (sham group), induced $\mathrm{BD}$ (BD group), and induced $\mathrm{BD}$ with concomitant $\beta$-blockade (BB group). BB animals were treated with $200-\mu \mathrm{g} /(\mathrm{kg} \cdot \mathrm{min})$ esmolol $\left(\mathrm{a} \beta_{1}\right.$-selective $\beta$-blocker with rapid onset, very short duration of action, and no significant intrinsic sympathomimetic or membrane stabilizing activity) for 30 minutes before induction of BD and for 45 minutes after BD.

Through a median sternotomy, piezoelectric ultrasound crystals (Sonometrics Corporation, London, Ontario, Canada) were placed in three axes on the heart to monitor cardiac function. Pressure transducer-tipped $2 \mathrm{~F}$ or $3 \mathrm{~F}$ catheters (Millar Instruments, Inc, Houston, Tex) were placed in both ventricles and the pulmonary artery. The subdural balloon was then inflated with $25 \mathrm{~mL}$ water during $1 \mathrm{~min}$ ute to induce $\mathrm{BD}$, which was confirmed by electroencephalography and correlated with changes in laser-detected blood flow. Cardiopulmonary function and intracranial pressure were monitored continuously throughout the experiment. Left ventricular end-diastolic volume was kept constant. After 6 hours of $\mathrm{BD}$, the animals were killed with sodium pentobarbital, and myocardial specimens were snap frozen in liquid nitrogen and stored at $-80^{\circ} \mathrm{C}$.

\section{Analysis of Cardiac Function}

Cardiosoft data analysis software (Sonometrics) was used to determine the derivative of the change in pressure over time and pressure-volume relationships. Preload recruitable stroke work (PRSW) was calculated from data collected during transient inferior vena caval occlusion. ${ }^{8}$

\section{Adenylate Cyclase Activity}

Cardiac sarcolemmal membranes (20 $\mu \mathrm{g}$ protein) were incubated for 15 minutes at $37^{\circ} \mathrm{C}$ with $\left[\alpha-{ }^{32} \mathrm{P}\right]$ adenosine triphosphate under basal conditions, $10^{-4}-\mathrm{mol} / \mathrm{L}$ isoproterenol (INN isoprenaline), or 10 $\mathrm{mmol} / \mathrm{L}$ sodium fluoride. The cAMP production was quantified by standard methods described previously. ${ }^{9}$

\section{Radioligand Binding}

Total $\beta$-AR density was determined by incubating $25 \mu \mathrm{g}$ cardiac sarcolemmal membranes with a saturating concentration of iodine 125-labeled cyanopindolol and $20-\mu \mathrm{mol} / \mathrm{L}$ alprenolol hydrochloride (INN alprenolol) to define nonspecific binding as previously described. ${ }^{7}$ Sarcolemmal membrane samples from all three groups were run in triplicate with $80-\mathrm{pmol} / \mathrm{L}\left[{ }^{125} \mathrm{I}\right]$ cyanopindolol and $10^{-4}-\mathrm{mol} / \mathrm{L}$ isoproterenol in $250 \mu \mathrm{L}$ binding buffer $(50-\mathrm{mmol} / \mathrm{L}$ N-2-hydroxyethylpiperazine-N-2-ethanesulfonic acid [pH 7.3], $5-\mathrm{mmol} / \mathrm{L}$ magnesium chloride, and $0.1-\mathrm{mmol} / \mathrm{L}$ ascorbic acid). The reactions were performed at $37^{\circ} \mathrm{C}$ for 1 hour and then filtered over GF/C glass fiber filters (Whatman plc, Maidstone, United Kingdom) that were washed twice and counted in a gamma counter. Data were analyzed by nonlinear least squares curve fitting (Prism; GraphPad Software, Inc, San Diego, Calif).

\section{Protein Immunoblotting}

Determination of expression of GRK2 in myocardial sarcolemmal membranes was performed on tissue extracts as previously described. ${ }^{7}$ Tissue was homogenized in ice-cold lysis buffer (25-mmol/L tris[hydroxymethyl]aminomethane hydrochloride $[\mathrm{pH}$ 7.5], 5-mmol/L EDTA, 5-mmol/L ethyleneglycol-bis-[ $\beta$-aminoethylether]-N,N,N ${ }^{\prime} \mathrm{N}^{\prime}$-tetraacetic acid, $10-\mu \mathrm{g} / \mathrm{mL}$ leupeptin, $20-\mu \mathrm{g} / \mathrm{mL}$ aprotinin, and 1-mmol/L phenylmethylsulfonyl fluoride). Nuclei and tissue were separated by centrifugation at $800 \mathrm{~g}$ for 20 minutes. The crude supernatant was then centrifuged at $20,000 \mathrm{~g}$ for $20 \mathrm{~min}$ utes. Sedimented proteins (membrane fraction) were resuspended in 50-mmol/L N-2-hydroxyethylpiperazine-N-2-ethanesulfonic acid 
(pH 7.3) and 5-mmol/L magnesium chloride. The immunodetection of myocardial levels of GRK2 with a polyclonal antibody (Santa Cruz Biotechnology, Inc, Santa Cruz, Calif) was performed on an equal amount of protein from membrane extracts $(70 \mu \mathrm{g})$ electrophoresed through $10 \%$ tris(hydroxymethyl)aminomethane/glycine gels and transferred to nitrocellulose. Membranes were blocked in 5\% nonfat dried milk in $0.1 \%$ polysorbate 20 in phosphate-buffered saline solution for 1 hour at room temperature. The protein was visualized with a horseradish peroxidase-linked secondary antibody and enhanced chemiluminescence detection (Amersham Pharmacia Biotech AB, Uppsala, Sweden).

\section{GRK Activity by Rhodopsin Phosphorylation}

The membrane fractions of the myocardial extracts were used to determine GRK activity. Extracts (120 $\mu \mathrm{g}$ protein) were incubated with rhodopsin-enriched rod outer-segment membranes in reaction buffer containing the following: 10-mmol/L magnesium chloride, 20-mmol/L tris(hydroxymethyl)aminomethane hydrochloride, 2-mmol/L EDTA, 5-mmol/L ethyleneglycol-bis-( $\beta$-aminoethylether)-N,N, $\mathrm{N}^{\prime}, \mathrm{N}^{\prime}$-tetraacetic acid, and $0.1-\mathrm{mmol} / \mathrm{L}$ adenosine triphosphate (containing $\left[\alpha-{ }^{32} \mathrm{P}\right]$ adenosine triphosphate), as previously described. ${ }^{6}$ After incubation in white light for 15 minutes at room temperature, reactions were quenched with ice-cold lysis buffer, and preparations were centrifuged for 15 minutes at $13,000 \mathrm{~g}$. Sedimented proteins were resuspended in $25 \mu \mathrm{L}$ protein-gel-loading dye and treated with $12 \%$ sodium dodecylsulfate-polyacrylamide gel electrophoresis. Phosphorylated rhodopsin was visualized by autoradiography of dried polyacrylamide gels and quantified with a Molecular Dynamics PhosphorImager (Molecular Dynamics, Inc, Sunnyvale, Calif).

\section{Statistical Analysis}

Repeated-measures analysis of variance was used to analyze serial data across time within treatment groups. Analyses were conducted with StatView 4.01 software (SAS Institute, Inc, Cary, NC). Experimental groups were compared with the Student $t$ test or 1-way analysis of variance, as appropriate. The Bonferroni test was applied to all significant analysis of variance results with SigmaStat software (Systat Software, Inc, Point Richmond, Calif). All results are expressed as mean $\pm \mathrm{SEM}$.

\section{Results}

\section{In Vivo Cardiac Physiology}

Baseline left ventricular PRSW was similar among BD, sham, and BB groups (BD $43.3 \pm 3.1$ vs sham $43.7 \pm$ 5.5 vs $\mathrm{BB} 38.2 \pm 1.9, P>.05$; Figure $1, A$ ). PRSW was significantly decreased 6 hours after BD in the BD group relative to the sham group $(21.4 \pm 3.4$ vs $36.2 \pm 3.8$, $P<.05$; Figure $1, A)$, indicating a marked decline in left ventricular systolic function after BD. In contrast, $\beta$-blockade resulted in preservation of left ventricular PRSW at 6 hours after $\mathrm{BD}(\mathrm{BB} 38.2 \pm 1.9$ vs BD $21.4 \pm 3.4, P<.05$; Figure 1, A). Consistent with these findings, left ventricular $\mathrm{dP} / \mathrm{dt}_{\text {min }}$, a measure of diastolic function, was significantly impaired 6 hours after BD relative to the sham group and maintained in the $\mathrm{BB}$ group $(\mathrm{BD}-250 \pm 38 \mathrm{~mm} \mathrm{Hg} / \mathrm{s}$ vs sham $-549 \pm 71 \mathrm{~mm} \mathrm{Hg} / \mathrm{s}$ vs $\mathrm{BB}-596 \pm 81 \mathrm{~mm}$
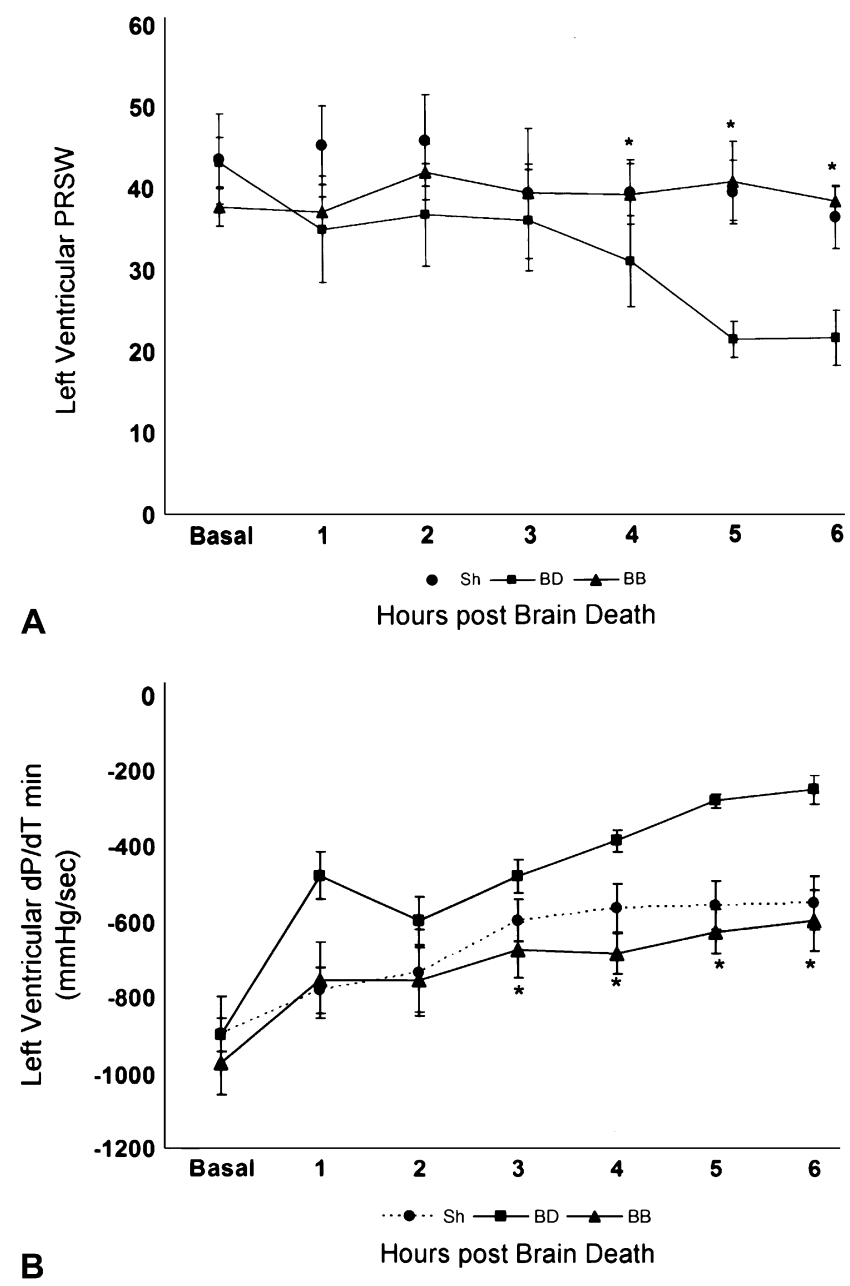

Figure 1. A, Left ventricular preload recruitable stroke work (PRSW) at baseline and after sham operation (Sh, circles, $\mathrm{n}=$ $8)$, induction of brain death ( $B D$, squares, $n=8)$, and induction of brain death with $\beta$-blocker therapy ( $B B$, triangles, $\mathrm{n}=8$ ). Asterisk indicates $\boldsymbol{P}<.05$ versus brain death and $\boldsymbol{P}>.05$ versus sham. $B$, Left ventricular $\mathrm{dP} / \mathrm{dt}_{\min }$ at baseline and after sham operation ( $S h$, circles, $\mathrm{n}=8$ ), induction of brain death $(B D$, squares, $\mathrm{n}=8$ ), and induction of brain death with $\beta$-blocker therapy (BB, triangles, $\mathrm{n}=8$ ). Asterisk indicates $P<.05$ versus brain death and $\boldsymbol{P}>.05$ versus sham.

$\mathrm{Hg} / \mathrm{s}, P<.05$; Figure $1, B)$. There was marked improvement in the $\mathrm{BB}$ group relative to the BD group $(-596 \pm$ $81 \mathrm{~mm} \mathrm{Hg} / \mathrm{s}$ vs $-250 \pm 38 \mathrm{~mm} \mathrm{Hg} / \mathrm{s}, P<.05)$. These indices of systolic and diastolic function indicate impaired myocardial function after $\mathrm{BD}$ and are consistent with previously described animal models. ${ }^{4,5}$ Improvement in both left ventricular PRSW and left ventricular $\mathrm{dP} / \mathrm{dt}_{\text {min }}$ suggests preservation of both systolic and diastolic function after $\mathrm{BD}$ in animals treated with esmolol. 


\section{Myocardial $\beta$-AR Signaling}

To study the effects of $\mathrm{BD}$ on myocardial $\beta$-AR signaling, we assessed receptor-effector coupling in sarcolemmal membranes from hearts in $\mathrm{BD}$, sham, and $\mathrm{BB}$ groups by measuring adenylate cyclase (AC) activity. Basal AC activity was blunted in the $\mathrm{BD}$ group relative to the sham and $\mathrm{BB}$ groups (BD $25.7 \pm 2.0 \mathrm{pmol} \mathrm{cAMP} /[\mathrm{mg} \cdot \mathrm{min}]$ vs sham $58.8 \pm 4$ $\mathrm{pmol} \mathrm{cAMP} /[\mathrm{mg} \cdot \mathrm{min}]$ vs BB $55.4 \pm 12 \mathrm{pmol} \mathrm{cAMP} /[\mathrm{mg}$ - min], $P<.001$; Figure 2). Isoproterenol-stimulated AC activity was also significantly lower after $\mathrm{BD}$ than in the sham and BB groups (BD 55.6 \pm 8 pmol cAMP/[mg . $\mathrm{min}]$ vs sham $124 \pm 20 \mathrm{pmol} \mathrm{cAMP} /[\mathrm{mg} \cdot \mathrm{min}]$ vs $\mathrm{BB}$ $124 \pm 27 \mathrm{pmol} \mathrm{cAMP} /[\mathrm{mg} \cdot \mathrm{min}], P<.005$; Figure 2$).$ AC activity stimulated by sodium fluoride, which induces maximal activity of $\mathrm{AC}$ by $\mathrm{G}_{\alpha \mathrm{s}}$ stimulation, was similar in all groups $(474 \pm 88 \mathrm{pmol} \mathrm{cAMP} /[\mathrm{mg} \cdot \mathrm{min}]$ vs $381 \pm$ $120 \mathrm{pmol} \mathrm{cAMP} /[\mathrm{mg} \cdot \mathrm{min}]$ vs $310 \pm 76 \mathrm{pmol} \mathrm{cAMP} /[\mathrm{mg}$ $\cdot \min ], P>.05$ ), indicating that the $\mathrm{G}$ protein-AC moiety is intact in all groups. This blunting of basal and agoniststimulated AC activity after BD suggests that uncoupling of myocardial $\beta$-ARs occurs early after BD. The preservation of AC activity in the animals that underwent $\beta$-blockade also indicates that $\beta$-AR receptor desensitization can be acutely inhibited with this medical therapy.

\section{Myocardial $\beta$-AR Density and G Protein Expression}

Total myocardial sarcolemmal membrane $\beta$-AR density was measured 6 hours after induction of BD or sham operation, and no differences were noted among groups (sham $121.5 \pm$ $31 \mathrm{fmol} / \mathrm{mg}$ vs BD $132.15 \pm 14.7 \mathrm{fmol} / \mathrm{mg}$ vs BB $141.7 \pm$ $33.2 \mathrm{fmol} / \mathrm{mg}, P>.05$; Figure 3). Acute $\beta$-blockade did not have an effect on myocardial $\beta$-AR density. These data indicate that $\beta$-AR desensitization rather than downregulation is an important mechanism of decreased ventricular

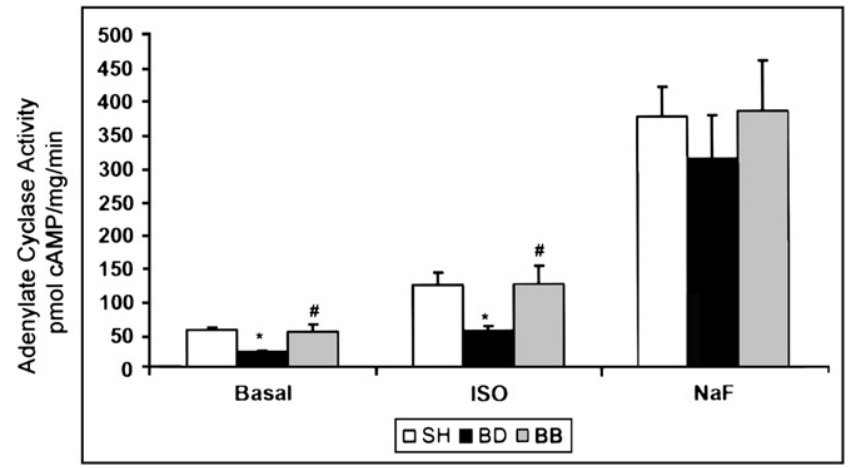

Figure 2. Myocardial sarcolemmal membrane adenylate cyclase activity 6 hours after sham operation ( $S h$, white columns, $n=8$ ), induction of brain death $(B D$, black columns, $\mathrm{n}=8)$, and induction of brain death with $\beta$-blocker therapy ( $B B$, gray columns, $\mathbf{n}=8$ ). $C A M P$, Cyclic adenosine monophosphate; $I S O, 1^{-4}$-mol/L isoproterenol; $\mathbf{N a F}, 50-\mathrm{mmol} / \mathrm{L}$ sodium fluoride. Asterisk indicates $P<.03$ versus sham and $\beta$-blockade. Crosshatch indicates $P<.05$ versus brain death and sham.

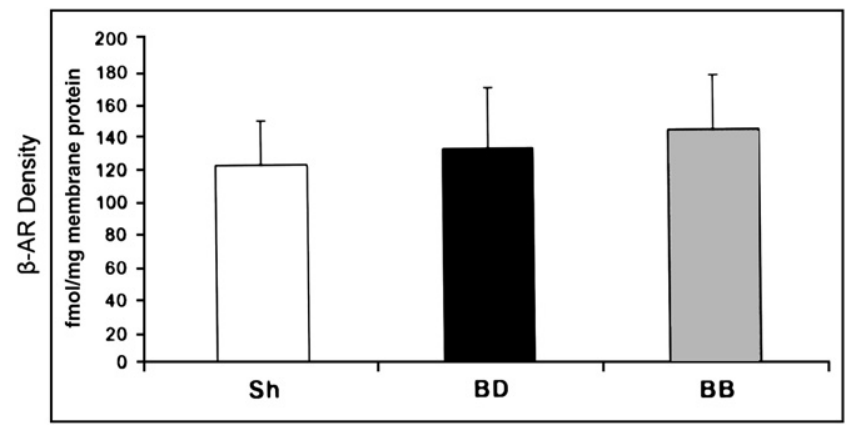

Figure 3. Myocardial sarcolemmal membrane $\beta$-adrenergic receptor $(\beta-A R)$ density 6 hours after sham operation (Sh, white columns, $\mathrm{n}=8)$, induction of brain death $(B D$, black columns, $n=8)$, and induction of brain death with $\beta$-blocker therapy (BB, gray columns, $\mathrm{n}=8$, each group performed in triplicate). No statistical differences among groups were seen.

function after BD. Myocardial expression of the $\mathrm{G}$ protein subunits $\mathrm{G}_{\alpha \mathrm{s}}$ and $\mathrm{G}_{\alpha \mathrm{i}}$ were measured by protein immunoblotting, and there was no difference among groups before induction of BD or sham operation or at 6 hours after BD (data not shown).

\section{Myocardial GRK Expression and Activity}

Left ventricular GRK2 expression in the sarcolemmal membrane fraction 6 hours after BD was elevated relative to the sham group $(20.1 \pm 1$ densitometry units [DU] vs $13.1 \pm 1.2 \mathrm{DU}, P<.05$; Figure 4$)$. After treatment with esmolol, there was a significant decrease in membrane GRK2 expression in the BB group relative to the BD group at 6 hours $(11.4 \pm 1 \mathrm{DU}$ vs $20.1 \pm 1 \mathrm{DU}, P<.05]$. Total myocardial GRK2 expression was not different among the three groups before or after induction of BD or sham operation (data not shown). The increase in GRK2 expression in the membrane fraction after BD correlates with an increase in myocardial membrane GRK2 activity measured by rhodopsin phosphorylation in BD versus BB animals (218.6 \pm $8.1 \mathrm{DU}$ vs $130.2 \pm 4.4 \mathrm{DU}, P<.02$; Figure 5 ). We examined left ventricular myocardial membrane expression of GRK5, the other GRK expressed in the heart, by protein immunoblotting and found no difference among the three groups (data not shown). Thus the attenuation of sarcolemmal membrane GRK2 expression and activity after intravenous $\beta$-blockade suggests that GRK2 activity and $\beta$-AR desensitization can be acutely inhibited with this medical approach.

\section{Discussion}

Potential donor heart dysfunction presents an additional limitation to cardiac transplantation for patients with endstage HF. Impaired myocardial $\beta$-AR signaling has been shown to be an important mechanism, because this receptor system is critical to the regulation of cardiac function. We 

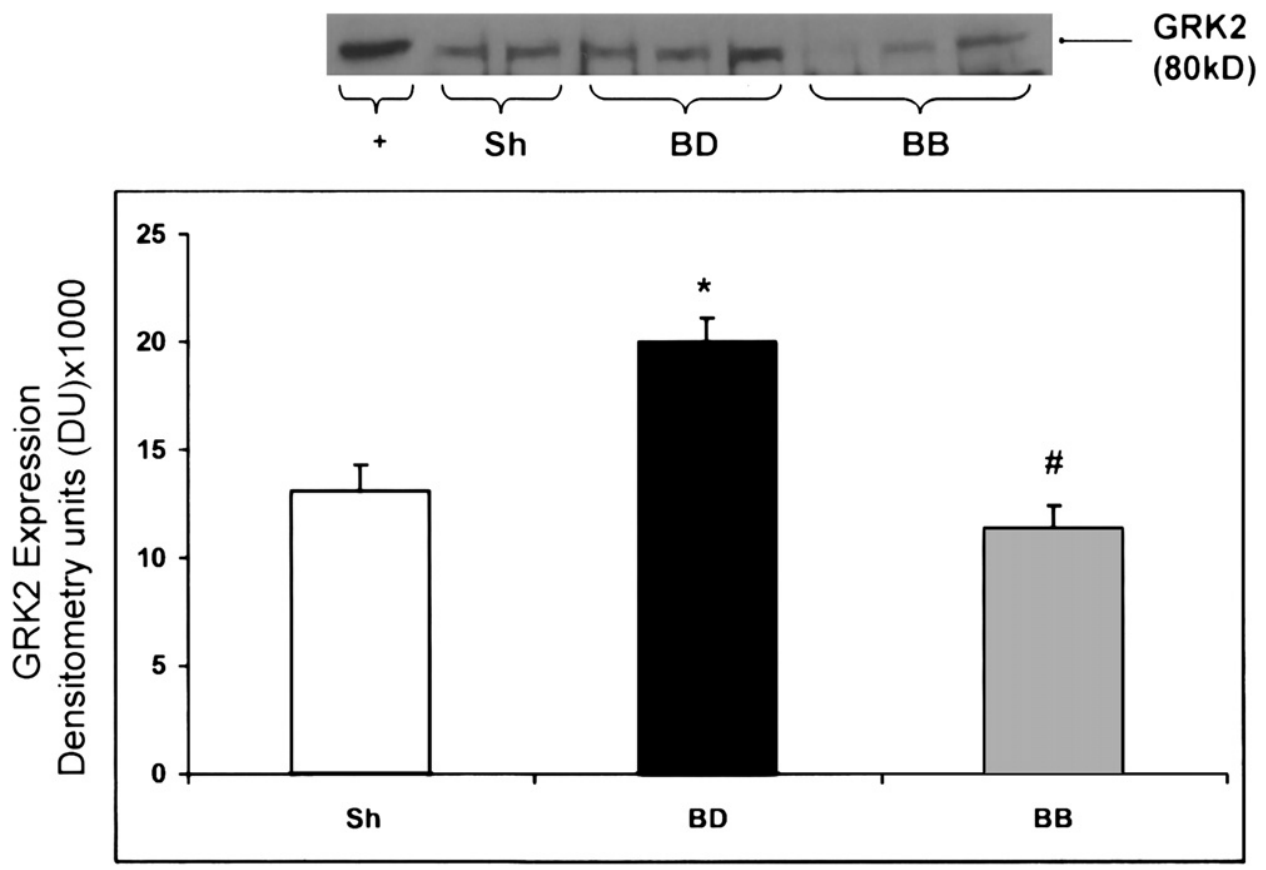

Figure 4. Myocardial sarcolemmal membrane G protein-coupled receptor kinase 2 (GRK2) expression 6 hours after sham operation ( $S h$, white columns, $\mathrm{n}=8)$, induction of brain death $(B D$, black columns, $\mathrm{n}=8)$, and induction of brain death with $\beta$-blocker therapy ( $B B$, gray columns, $\mathrm{n}=8$, each group performed in triplicate). Asterisk indicates $\boldsymbol{P}<.05$ versus sham. Crosshatch indicates $\boldsymbol{P}<.05$ versus $B D$ and $\boldsymbol{P}>.05$ versus sham. Plus sign represents positive control.

have previously shown in an experimental model that uncoupling, or desensitization, of myocardial $\beta$-ARs after BD results from activation of GRK2. ${ }^{7}$ GRK2 is a member of the GRK family of serine-threonine kinases, which phosphorylate and inhibit further signaling through specific agonist-occupied receptors. GRK2, the primary GRK expressed in the heart, is an important mediator of ventricular function in vivo. ${ }^{5,10}$ The primary targets of GRK2 phosphorylation in the heart are $\beta$-ARs. The focus of this study was to investigate more specifically the significance and mechanism of impaired $\beta$-AR signaling in ventricular function after BD and to determine whether acute $\beta$-blockade could inhibit $\beta$-AR desensitization and maintain cardiac function in an experimental model of BD and ventricular dysfunction.

Our data demonstrate that impaired $\beta$-AR signaling is an important cause of early ventricular dysfunction after BD. The primary mechanism for this appears to be increased GRK2 activity, leading to desensitization of $\beta$-ARs and impaired receptor-effector coupling. BD is associated with an acute catecholamine surge, and circulating levels of the adrenal hormones norepinephrine and epinephrine are greatly elevated. ${ }^{11}$ This leads to significantly enhanced myocardial $\beta$-AR stimulation and the hypertensive and tachycardic phenotype characteristic of $\mathrm{BD}$.
GRK2 activity is then elevated, leading to early impairment in $\beta$-AR signaling and thus ventricular dysfunction. Although this impaired $\beta$-AR signaling resulting from GRK2 activation would be expected to be transient after the catecholamine surge, our data suggest that GRK2 activity is increased and myocardial $\beta$-AR desensitization is present at least as long as 6 hours after the induction of BD. Studies of this mechanism of early donor heart dysfunction need to be performed at longer intervals after $\mathrm{BD}$ to determine whether impaired $\beta$-AR signaling persists at 18 to 24 hours.

We have previously shown that long-term left ventricular assist device support in patients with end-stage HF can restore myocardial $\beta$-AR signaling to normal levels and that the primary mechanism is through decreases in GRK2 expression and activity, which appear to be due to a decline in circulating catecholamine levels after normalization of hemodynamics. ${ }^{12}$ This is the only demonstration to date of an intervention that can regulate ventricular GRK2 activity and effect $\beta$-AR signaling in human beings. Previously published work from our laboratory showed that long-term $\beta$-blocker treatment in mice can lower myocardial GRK2 activity and lead to enhanced $\beta$-AR signaling in the heart. ${ }^{13}$ The effects of acute $\beta$-blockade on this signaling pathway 

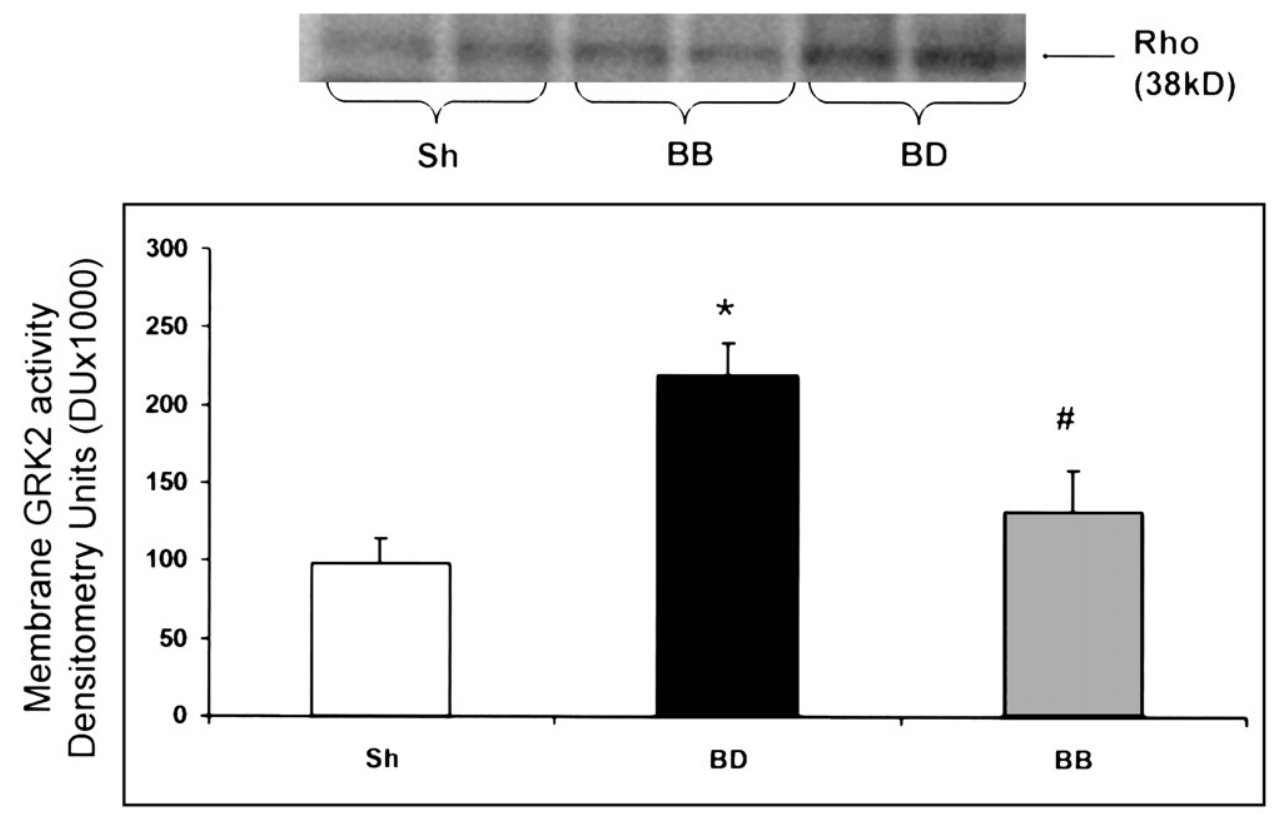

Figure 5. G protein-coupled receptor kinase 2 (GRK2) activity in myocardial sarcolemmal membrane preparations 6 hours after sham operation ( $S h$, white columns, $n=8)$, induction of brain death $(B D$, black columns, $n=8)$, and induction of brain death with $\beta$-blocker therapy ( $B B$, gray columns, $n=8$, each group performed in triplicate). Rho, Rhodopsin. Asterisk indicates $P<.02$ versus sham. Crosshatch indicates $P<.01$ versus $B D$ and $P>.05$ versus sham.

and ventricular function have not been studied. We administered esmolol, a cardioselective $\beta_{1}$-AR blocker with a very short duration of action, before the induction of BD to determine whether the acute $\beta$-AR desensitization associated with the catecholamine surge could be prevented or diminished, leading to preservation of normal ventricular function early after BD. Acute $\beta$-blockade did in fact prevent myocardial $\beta$-AR desensitization after $\mathrm{BD}$, as measured by left ventricular sarcolemmal membrane basal and isoproterenol-stimulated AC activity. AC activity in the esmolol-treated group was preserved and did not differ from that in sham-operated control subjects. In addition, there was no increase in myocardial GRK2 activity in animals receiving esmolol before $\mathrm{BD}$ relative to the 3-fold elevation in GRK2 activity present in the BD group, which did not receive esmolol. Our data demonstrate for the first time that acute $\beta$-blockade can prevent myocardial $\beta$-AR desensitization in the setting of increased $\beta$-agonist stimulation resulting from inhibition of GRK2 activity. This led to preservation of left ventricular function after $\mathrm{BD}$ relative to animals that did not receive esmolol treatment before BD and did have significant ventricular dysfunction. These data also highlight the importance of impaired $\beta$-AR signaling as a mechanism in poor myocardial function after BD.

These experiments were performed as a proof-of-principle study to determine more specifically the significance of impaired $\beta$-AR signaling in cardiac dysfunction after BD.
For that reason, animals were treated with esmolol before induction of BD. Further studies should be performed to evaluate the efficacy of acute $\beta$-blocker therapy immediately after the onset of $\mathrm{BD}$, which is a more clinically applicable situation. Although the catecholamine surge associated with BD is transient, we have shown that elevated GRK2 activity and impaired $\beta$-AR signaling are present for as long as 6 hours after $\mathrm{BD}$, with continued ventricular dysfunction. It appears reasonable to hypothesize on the basis of these findings that $\beta$-blocker therapy administered just after the onset of BD may be effective in the preservation of myocardial $\beta$-AR signaling and cardiac function. In addition to $\beta$-blockade, direct inhibition of GRK2 activity may be possible in the future through use of a previously described peptide inhibitor of this kinase. ${ }^{5,14}$ Inhibition of GRK2 activity through gene transfer of this peptide in vitro and in vivo resulted in significantly enhanced $\beta$-AR signaling and cardiac myocyte or ventricular contractility. $^{14-17}$ Strategies to inhibit $\beta$-AR desensitization by GRK 2 may represent a novel approach to preventing early donor heart dysfunction, potentially increasing the number of organs that can be procured for cardiac transplantation.

\section{References}

1. Florea VG, Anand IS. Predicting survival in heart failure. Curr Cardiol Rep. 2007;9:209-17.

2. Halejcio-Delophont P, Siaghy EM, Devaux Y, Richoux JP, Bischoff N, Carteaux JP, et al. Consequences of brain death on coronary blood flow and myocardial metabolism. Transplant Proc. 1998;30:2840-1. 
3. White M, Wiechmann RJ, Roden RL, Hagan MB, Wollmering MM, Port JD, et al. Cardiac $\beta$-adrenergic neuroeffector systems in acute myocardial dysfunction related to brain injury. Circulation. 1995;92:2183-9.

4. D'Amico TA, Meyers CH, Koutlas TC, Peterseim DS, Sabiston DC, Van Trigt $\mathrm{P}$, et al. Desensitization of myocardial $\beta$-adrenergic receptors and deterioration of left ventricular function after brain death. J Thorac Cardiovasc Surg. 1995;110:746-51.

5. Koch WJ, Rockman HA, Samama P, Hamilton R, Bond RA, Milano CA, et al. Cardiac function in mice overexpressing the $\beta$-adrenergic receptor kinase or a $\beta$ ARK inhibitor. Science. 1995;268:1350-3.

6. Akhter SA, Eckhart AD, Rockman HA, Shotwell K, Lefkowitz RJ, Koch WJ. In vivo inhibition of elevated myocardial $\beta$-adrenergic receptor kinase activity in hybrid transgenic mice restores normal $\beta$-adrenergic signaling and function. Circulation. 1999;100:648-53.

7. Pandalai PK, Lyons JM, Duffy JY, McLean KM, Wagner CJ, Merrill WM, et al. Role of the $\beta$-adrenergic receptor kinase in myocardial dysfunction following brain death. $J$ Thorac Cardiovasc Surg. 2005;130:1183-9.

8. Glower DD, Spratt JA, Snow ND, Kabas JS, Davis JW, Olsen CO, et al. Linearity of the Frank-Starling relationship in the intact heart: the concept of preload recruitable stroke work. Circulation. 1985;5:994-1009.

9. Salomon Y, Londos C, Rodbell M. A highly sensitive adenylate cyclase assay. Anal Biochem. 1974;58:541-8.

10. Rockman HA, Koch WJ, Lefkowitz RJ. Seven-transmembranespanning receptors and heart function. Nature. 2002;415: 206-12.
11. Chen EP, Bittner HB, Kendall SW, VanTrigt P. Hormonal and hemodynamic changes in a validated model of brain death. Crit Care Med. 1996; 24:1352-9.

12. Pandalai PK, Bulcao CF, Merrill WH, Akhter SA. Restoration of myocardial beta-adrenergic receptor signaling after left ventricular assist device support. J Thorac Cardiovasc Surg. 2006;131: 975-80.

13. Iaccarino G, Tomhave ED, Lefkowitz RJ, Koch WJ. Reciprocal in vivo regulation of myocardial G protein - coupled receptor kinase expression by $\beta$-adrenergic receptor stimulation and blockade. Circulation. 1998; 98:1783-9.

14. Akhter SA, Skaer CA, Kypson AP, McDonald PH, Peppel KC, Glower DD, et al. Restoration of $\beta$-adrenergic signaling in failing cardiac ventricular myocytes via adenoviral-mediated gene transfer. Proc Natl Acad Sci U S A. 1997;94:12100-5.

15. Koch WJ, Lefkowitz RJ, Rockman HA. Functional consequences of altering myocardial adrenergic receptor signaling. Апnи Rev Physiol. 2000;62:237-60.

16. Shah AS, White DC, Emani S, Kypson AP, Lilly RE, Wilson K, et al. In vivo ventricular gene delivery of a beta-adrenergic receptor kinase inhibitor to the failing heart reverses cardiac dysfunction. Circulation. 2001; 103:1311-6

17. White DC, Hata JA, Shah AS, Glower DD, Lefkowitz RJ, Koch WJ. Preservation of myocardial beta-adrenergic receptor signaling delays the development of heart failure after myocardial infarction. Proc Natl Acad Sci U S A. 2000;97:5428-33.

\section{ON THE MOVE?}

Don't miss a single issue of the journal! To ensure prompt service when you change your address, please photocopy and complete the form below.

Please send your change of address notification at least six weeks before your move to ensure continued service. We regret we cannot guarantee replacement of issues missed due to late notification.

\section{JOURNAL TITLE:}

Fill in the title of the journal here.

OLD ADDRESS:

Affix the address label from a recent issue of the journal here.
NEW ADDRESS:

Clearly print your new address here.

Name

Address

City/State/ZIP
COPY AND MAIL THIS FORM TO:

Elsevier Inc.

Subscription Customer Service

6277 Sea Harbor Dr

Orlando, FL 32887
OR FAX TO:

407-363-9661

OR E-mail:

elspcs@elsevier.com
OR PHONE:

800-654-2452

Outside the U.S., call

407-345-4000 